\title{
The Change with Age of the Copulatory Behavior of the Male Rats Aged 67 and 104 Weeks
}

\author{
Ryoji HOKAO, Toru R. SAITO*, Yasumasa WAKAFUJI, \\ Kazuaki W. TAKAHASHI*, and Tomonori IMAMICHI \\ The Imamichi Institute for Animal Reproduction, 1103 Fukaya, Dejima-mura, Niihari-gun, \\ Ibaraki 300-01 and "Department of Laboratory Animal Science, Nippon Veterinary and \\ Animal Science University, 1-7-1 Kyonan-cho, Musashino-shi, Tokyo 180,Japan
}

(Received 2 September 1992/Accepted 29 September 1992)

\begin{abstract}
Changes with age in sexual fertility in male rats of the Wistar-Imamichi strain were investigated. Litter size and numbers of implantation sites in females mated with males aged 14 to 44 weeks tended to decrease with increased aging of males. These indicators in females mated with males aged over than 44 weeks decreased, compared with that aged 14 to 44 weeks $(\mathrm{P}<0.05$ to 0.001$)$. In addition, all females mated with males aged 95 weeks were not pregnant. In male copulatory behavior with aging, incidences and numbers of mounting at 67 and 104 weeks of age were $100 \%, 42.6 \pm 15.3$

(Mean \pm S.D.) and $42 \%, 1.8 \pm 2.8$, respectively. The intromission and ejaculation were observed at 67 weeks, but not at 104 weeks of age. These incidences and frequencies were $86 \%, 10.3 \pm 10.2$ for intromission, and $43 \%, 1.0 \pm 1.3$ for ejaculation. Mount latencies (ML) at 67 and 104 weeks of age were 535.4 \pm 607.9 and $3,822.0 \pm$ $1,753.4 \mathrm{sec}$, respectively. There were significant differences in ML between two groups $(\mathrm{P}<0.05)$. At 67 weeks of age, intromission and ejaculation latencies, and post-ejaculatory intervals were $2,563.0 \pm 2,216.3,1,633.7 \pm 977.6$, and $657.3 \pm 320.6$ $\mathrm{sec}$, respectively. The pregnant rate and numbers of implantation sites in females mated with males aged 67 weeks were $43 \%$ and $5.4 \pm 6.8$, respectively. In females mated with males aged 104 weeks, all were not pregnant. The weights of testes, epididymides, ventral prostate and seminal vesicles at 104 weeks were light, compared with those at 67 weeks of age $(P<0.05)$. From these results, the copulatory behavior in male rats of the Wister-Imamichi strain declined with aging. Sexual fertility in males aged 67 weeks decreased in less than $50 \%$, and males aged 104 weeks showed no intromission and ejaculation. - KEY WORDS : aging, copulation, male rats, sexual fertility
\end{abstract}

\section{雄ラットの加齢時における交尾行動の変化 \\ 外尾亮治・斎藤徹*・若藤靖匡・高橋和明*・今道友則 \\ 財団法人動物繁殖研究所 \\ *日本獣医畜産大学実験動物学教室}

ヒトを始めとする哺乳動物の性行動は加䚟に伴い 隇退することが良く知られている [1]。例えば, 高 跲の雄動物では, 発情雌に対する, 乗駕, 挿入, 射 精回数などの減少が観察されている $[3,11]$ 。雄ラッ トについては, Larsson [9]および Minnick ら [10]
の報告が見られるが, 詳細な検討はなされていない。 そこで著者らは繁殖生理学的研究に適する動物とし て育種された Wistar-Imamichi 系ラット［7］を用 い, 雄交尾行動の若龄から老舲時にわたる変化につ いて研究することを計画した。既報 [6] では, 生後 
10，27および44週㱓の雄ラットの交尾行動を詳細に 観察した。その結果, 交尾行動は加龄に伴って減退 し，44週秢時の妊孕能は10および27週秢時に比べて 低下していた。

本報では，既報 [6] の生後44週龄時の交尾行動の 観察に引き続き, 妊孕能が急減する時期の67週㱓お よび妊孕能消失時期の 104 週齢（2 年秢）の交尾行 動について検討した。

\section{材料および方法}

実験環境：動物は室温 $25 \pm 1{ }^{\circ} \mathrm{C}$, 湿度 $60 \pm 5 \%$, オールフレッシュエアー方式による換気回数 1 時間 12 回，人工照明時間14時間（午前 5 時 午後 7 時) に設定されたラット用動物室で飼育された。雄動物 は, 14週秢から種親として交配に供されている間は, ステンレス製金網ケージ $(300 \mathrm{~W} \times 400 \mathrm{D} \times 200 \mathrm{H}$ $\mathrm{mm}$ )に原則として 1 匹飼育された。固型飼料 (日本 チャールス・リバー株式会社製 CRF-1）および井戸 水（塩素濃度 $7 \mathrm{ppm}$ に調製）を不断給与した。

実験 I . 雄妊㭆能の加䊩に伴う推移の検討

1) 供試動物：（財）動物繁殖研究所で自家生産 された Iar:Wistar-Imamichi 系 (Wistar 由来) [7] のSPF ラット雄20匹，雌2,600 匹を使用した。雄動 物は種動物として 14 週龄から 34 週秢まで $8 \sim 10$ 週粭 の発情雌と 1 対 1 で週 2 回の交配に供されたもの で, その中から20匹を無作為に選び出し, 妊孕能が 消失するまでの間,毎週 1 から 2 回の交配に供した。

2 ）妊㔔能の観察：種雄として使用されている34 週粭までは交配䧳について分婏当日に産子数を調べ た。35週秢以降は交配䧳について交配翌日を妊娠 0 日として, 妊娠 7 日目相当日に剖検した。そして妊 娠しているものについては着床数を調へ，不妊のも のについては子宮の状態から性周期を回帰している か否かを調べた。

実験II. 雄交尾行動の加秢時の変化の検討

1）供試動物：行動の観察に供した67週秢の雄動 物は, 32 週秢まで種動物として使用し，その後，週 1 から 2 回の交配に供したものの中から 67 週秢で無 作為に抽出した 7 匹を使用した。104週柃の雄動物 は, 実験 I で好孕能消失時期の検討に用いた12匹を 使用した。交配に使用した $8 \sim 10$ 週秢の発情雌の匹 数は392匹であった。

2 ) 交尾行動の観察 (録画)：予め午後 6 時より観
察用ケージ $(300 \mathrm{~W} \times 400 \mathrm{D} \times 200 \mathrm{H} \mathrm{mm})$ に収容され ている雄と用手法でロードーシスを確認した発情雌 とを午後 7 時に同居させ, 赤外線照射暗黑下で同居 開始後 2 時間, ビデオテープレコータ(Panasonic Time Lapse AG6020)で交尾行動を録画した。

3 ）交尾行動の記録と作困：録画テープから，乗 鴐, 挿入および射精の行動時刻を記録し,コンピュー 夕に入力した。ついで，入力した行動時刻を同居開 始後の秒数に変換し, 横軸に同居開始後の秒数, 縦 軸に乗駕 (Mount；M)，找入 (Intromission；I）およ び射精(Ejaculation；E)の順に高さをとり，横軸を 基点とする直線の長さで同居開始後の交尾行動を表 わし，個体ごとに，観察時間中の交尾行動をグラフ 化した。なお，コンピュータ(NEC PC9801-RX2) と プリンター(NEC PC-PR602PS)を使用し，自製の プログラム(BASIC および Post Script 言語を使 用）で作困した。

4 ）交尾行動の測定：観察 2 時間に示した雄の交 尾行動を次の各指標 [5]を用いて定量的に測定した。

(1)乗駕回数 (Mount frequency)；挿入を伴わな い乗駕のみの回数。

(2)扱入回数 (Intromission frequency) ; 㨂入を伴 う乗駕回数。

(3)射精回数 (Ejaculation frequency) ; 射精を伴 莱駕回数。

(4)乗駕潜時 (Mount latency) ; 同居開始から最初 の乗駕が起こるまでの時間。

(5)扱入潜時 (Intromission latency) ; 同居開始か ら最初の挿入が起こるまでの時間。

(6)射精潜時 (Ejaculation latency)；最初の扱入 から射精の生じるまでの時間。

(7)射精後挿入間間隔 (Post-ejaculatory Interval）；射精から次の交尾シリーズの最初の㨂入ま での時間。

5 ）雄の生殖器重量および雃の着床痕の検査：雄 では，交尾による影響を考虑して，交尾行動観察後 4 日目に解剖し, 精巣, 精巣上体, 精襄腺, 前立腺 腹葉および陰菱の重量を測定 (メトラ社製 PM-100) した。雌では, 観察後 8 日目に開腹して, 着床の有 無を検索した。

統計処理 : Student's t test および Fisher's exact test を使用して $5 \%, 1 \%$ よび $0.1 \%$ 水準での有意 差を検定した [12]。 


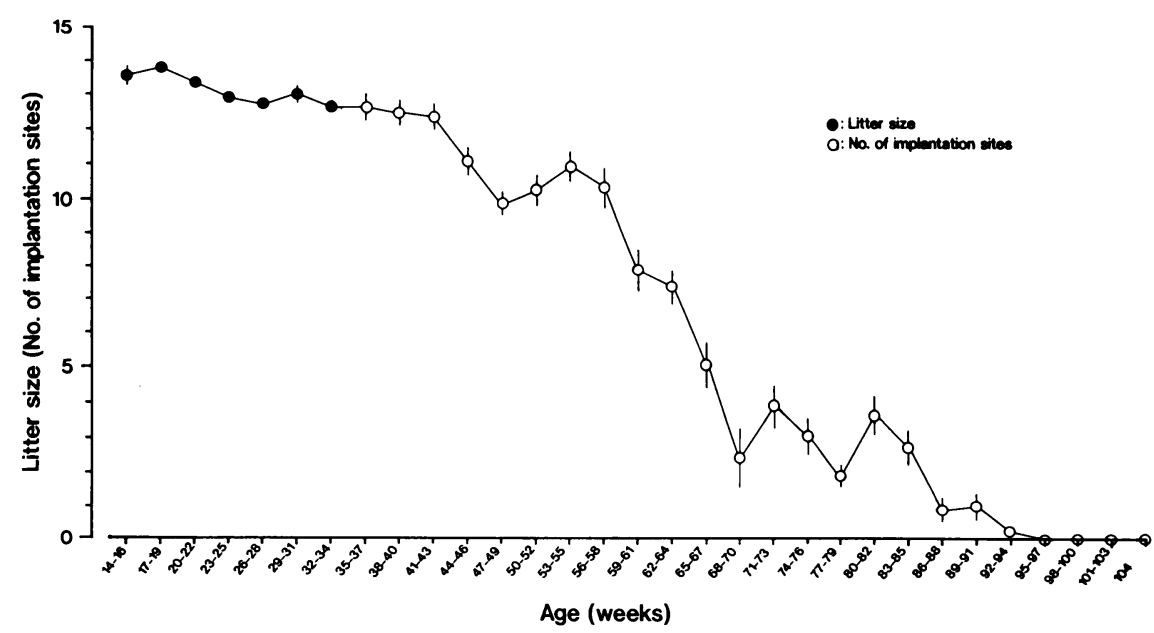

Fig. 1. Changes of sexual fertility in male rats $(n=20)$ with increased aging. Litter sizes at parturition and numbers of implantation sites at 9 days after mating were performed. All data represent Mean $\pm \mathrm{S}$. E. of 43 to 170 females.

Table 1. Copulatory behavior in male rats of two different age groups

\begin{tabular}{cccccccc}
\hline $\begin{array}{c}\text { Age } \\
\text { (weeks) }\end{array}$ & $\mathrm{n}$ & $\begin{array}{c}\text { No. of } \\
\text { Mounts } / 2 \text { hrs }\end{array}$ & $\%^{1)}$ & $\begin{array}{c}\text { No. of } \\
\text { Intromissions } / 2 \text { hrs }\end{array}$ & $\%$ & $\begin{array}{c}\text { No. of } \\
\text { Ejaculations } / 2 \text { hrs }\end{array}$ & $\%$ \\
\hline 67 & 7 & $\begin{array}{c}42.6 \pm 15.3^{2)} \\
(29-65)^{3)}\end{array}$ & 100 & $\begin{array}{c}10.3 \pm 10.2 \\
(0-26)\end{array}$ & 86 & $\begin{array}{c}1.0 \pm 1.3 \\
(0-3)\end{array}$ & 43 \\
104 & 12 & $\begin{array}{c}1.8 \pm 2.8 \\
(0-9)\end{array}$ & 42 & & 0 & & 0 \\
P value $^{4)}$ & 0.001 & 0.05 & & 0.001 & & 0.05 \\
\hline
\end{tabular}

1): Percent of animals responding ${ }^{2)}:$ Mean \pm S.D. ${ }^{3)}:$ Range ${ }^{4)}$ : Determined by student's $t$ or Fisher's exact tests

\section{成}

\section{実験 I . 雄妊孕能の加粭に伴う推移}

Fig. 1 に14週粭から妊孕能が消失するまでの間 に雄との交配に用いた雌の産子数（14週秢から34週 鮯の雄による）ならびに着床数（35週䀫から 104週 齢の雄による）の平均値（土標準偏差）を示した。 14週粭から40週粭まで，週粭が進むと共に産子数ま たは着床数は減少する傾向を示すが, 週秢間で統計

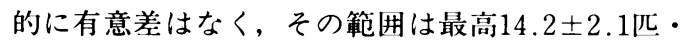

(個) 〜最低 $12.0 \pm 6.7$ 匹・(個) であった。しかし, 41週跲以降になると，44週粭頃より有意差が認めら れ始め $(\mathrm{P}<0.05 \sim 0.001) ， 44 \sim 57$ 週秢では11.7士

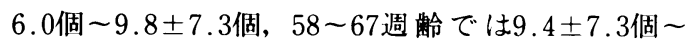
$4.6 \pm 7.0$ 個の範囲であった。その後も減少し, $68 \sim 85$
週秢では $4.5 \pm 6.8$ 個〜 $1.8 \pm 4.2$ 個の範讲となり，そ の後妊娠する個体は極めて少数となり，95週龄では 交配に供した雌すべてが不妊となった。

実験 II. 雄交尾行動の加秢時の変化

1. 乗駕, 挿入および射精の発現率と回数

Table 1 に67および104週䀫群が, 2 時間の観察期 間中に示した乗駕, 挿入, 射精の発現率と回数の各 平均値（土標準偏差）を表わし，Figs，2，3にそ の個体別成績を示した。

乗駕の発現率と回数：乗駕の発現率は67週舲群が $7 / 7$ 例 (100\%) に対し104週粭群では5/12例（42\%） となり有意に低下した $(\mathrm{P}<0.05)$ 。乗駕の平均回数

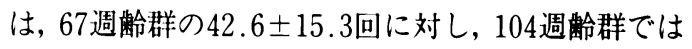
$1.8 \pm 2.8$ 回となり有意に減少した $(\mathrm{P}<0.001)$ 。

搟入の発現率と回数：挿入の発現率は67週舲群の 6/7例（86\%）に対し，104週㱓群では0/12（0\%） 

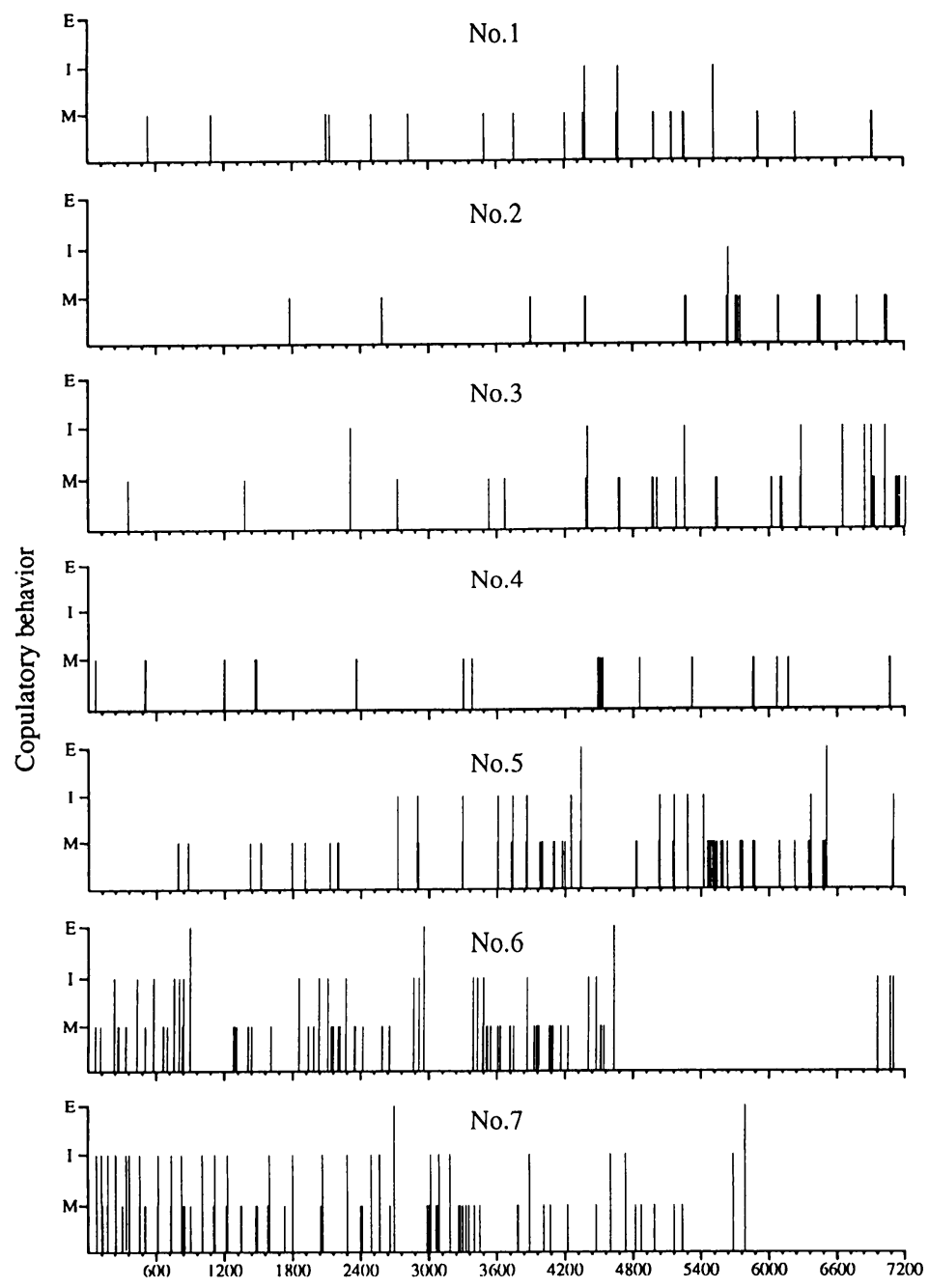

Fig. 2. Copulatory behavior in 67-week-old group $\mathrm{M}:$ mount $\mathrm{I}$ : intromission $\mathrm{E}$ : ejaculation

となり有意に低下した $(\mathrm{P}<0.001)$ 。67週㱓群の平均 挿入回数は $10.3 \pm 10.2$ 回であった。

射精の発現率と回数：射精の発現率は67週粆群の 3/7例 (43\%) に対し，104週秢群では0/12（0\%） となり有意に低下した $(\mathrm{P}<0.05)$ 。67週踰群の平均 射精回数は, $1.0 \pm 1.3$ 回であった。

2. 雄の乗鴐, 指入, 射精の各潜時と射精後挿入 間間隔

Table. 2 に67および104週制群の乗駕, 㨂入およ び射精の潜時と, 射精後㨂入間間隔の各平均値を示 した。
乗駕潜時: 同居開始から初回の乗駕までの平均乗

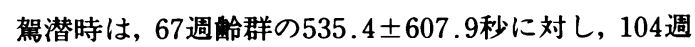
略群では $3,822.0 \pm 1,753.4$ 秒となり有意に延長した $(\mathrm{P}<0.05)$ 。

㨂入潜時: 同居開始から初回の㨂入までの平均捜 入潜時は, 67 週秢群が $2,563.0 \pm 2,216.3$ 秒であつ た。

射精潜時: 初回の㨂入から射精までの平均射精潜

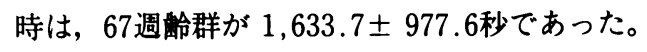
射精後挿入間間隔: 初回の射精から次の交尾シ リーズの最初の扱入までの Post-ejaculatory Inter- 


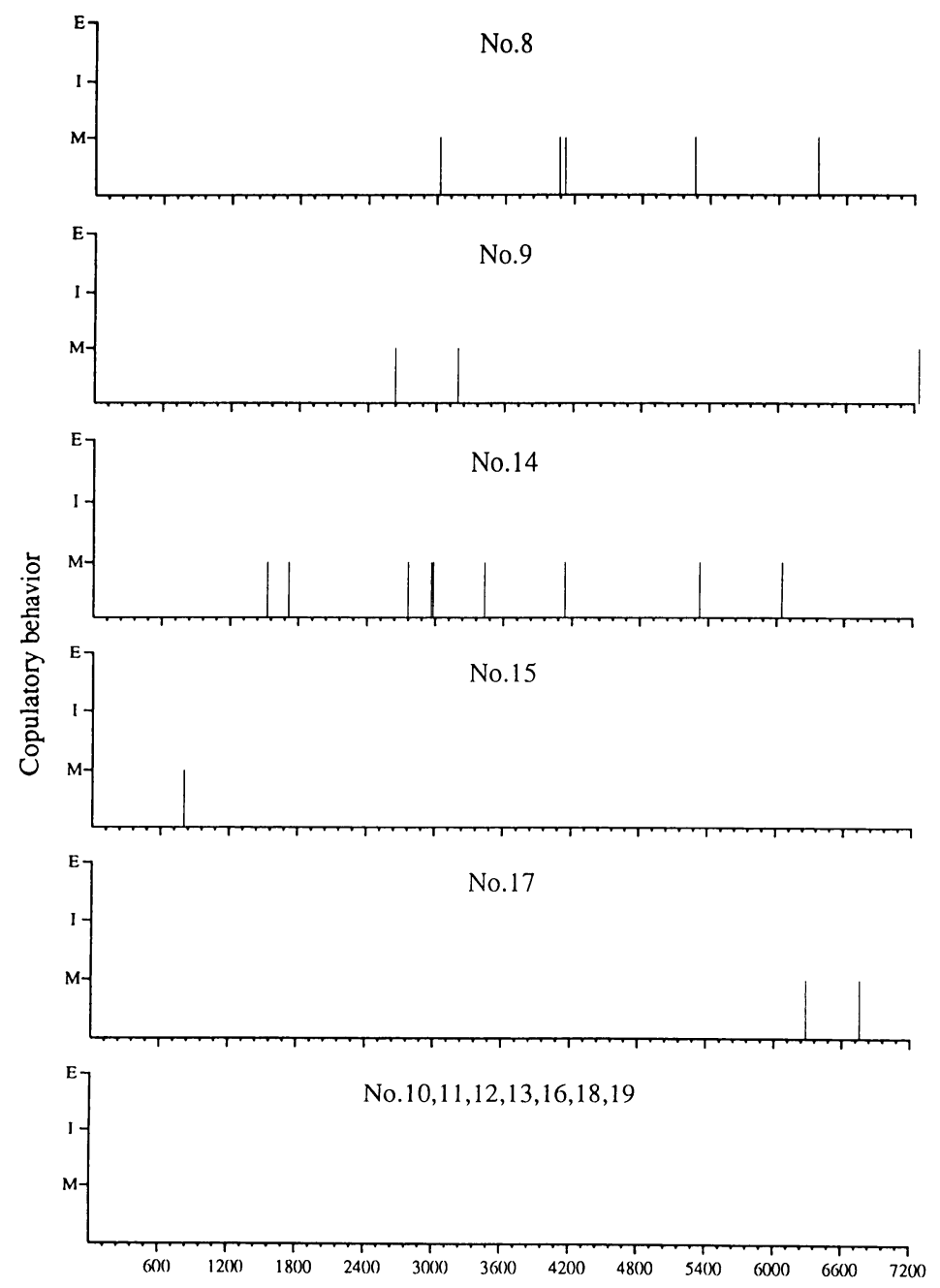

Fig. 3. Copulatory behavior in 104-week-old group M: mount $\mathrm{I}$ : intromission $\mathrm{E}$ : ejaculation

Table 2. Serial copulatory behavior in male rats of two different age groups

\begin{tabular}{|c|c|c|c|c|c|}
\hline $\begin{array}{c}\text { Age } \\
\text { (weeks) }\end{array}$ & $\mathrm{n}$ & $\begin{array}{c}\text { Mount } \\
\text { Latency (sec.) }\end{array}$ & $\begin{array}{l}\text { Intromission } \\
\text { Latency (sec.) }\end{array}$ & $\begin{array}{c}\text { Ejaculation } \\
\text { Latency }(\mathrm{sec} .)\end{array}$ & $\begin{array}{l}\text { Post-ejaculatory } \\
\text { Interval (sec.) }\end{array}$ \\
\hline 67 & 7 & $\begin{array}{c}535.4 \pm 607.9^{1) a} \\
\quad(62-1,776)^{2)}\end{array}$ & $\begin{array}{c}2,563.0 \pm 2,216.3 \\
(75-5,648)\end{array}$ & $\begin{array}{c}1,633.7 \pm 977.6 \\
\quad(665-2,620)\end{array}$ & $\begin{array}{c}657.3 \pm 320.6 \\
(320-958)\end{array}$ \\
\hline 104 & 12 & $\begin{array}{c}3,822.0 \pm 1,753.4^{\mathrm{b}} \\
(1,527-6,282)\end{array}$ & & & \\
\hline
\end{tabular}


Table 3. Numbers of implantation sites in females mated with male rats of two different age groups

\begin{tabular}{|c|c|c|c|c|c|}
\hline \multicolumn{2}{|r|}{ 67-week-old } & \multicolumn{4}{|c|}{ 104-week-old } \\
\hline $1^{1)}$ & 0 & 8 & 0 & 15 & 0 \\
\hline 2 & 0 & 9 & 0 & 16 & 0 \\
\hline 3 & 0 & 10 & 0 & 17 & 0 \\
\hline 4 & 0 & 11 & 0 & 18 & 0 \\
\hline 5 & $11(9,2)^{2)}$ & 12 & 0 & 19 & 0 \\
\hline 6 & $13(10,3)$ & 13 & 0 & & \\
\hline 7 & $14(8,6)$ & 14 & 0 & & \\
\hline & $5.4 \pm 6.8^{3)} \quad 43 \%{ }^{4) a}$ & & & 0 & $0 \%$ b \\
\hline
\end{tabular}

Females were sacrificed at eight days after observation of copulation. $\quad{ }^{1)}$ : Male number ${ }^{2)}$ : Total (left, right) 3) : Mean \pm S.D. ${ }^{4)}$ : Percent of animal responding Fisher's exact test $: \mathrm{P}<0.05 \mathrm{a}$ vs. $\mathrm{b}$

Table 4. Weights of body and reproductive organs in male rats of two different age groups

\begin{tabular}{lccc}
\hline $\begin{array}{c}\text { Body and } \\
\text { Organ Weights }\end{array}$ & & 67-week-old & 104-week-old \\
\hline Body & $(\mathrm{g})$ & $774 \pm 48^{1) \mathrm{a}}$ & $683 \pm 97^{\mathrm{b}}$ \\
Testes & $(\mathrm{mg})$ & $2,967 \pm 183^{\mathrm{c}}$ & $2,248 \pm 852^{\mathrm{d}}$ \\
Epididymides & $(\mathrm{mg})$ & $1,203 \pm 73^{\mathrm{e}}$ & $999 \pm 271^{\mathrm{f}}$ \\
Ventral Prostate & $(\mathrm{mg})$ & $983 \pm 309$ & $857 \pm 347$ \\
Seminal vesicles & $(\mathrm{mg})$ & $2,296 \pm 358^{\mathrm{g}}$ & $1,680 \pm 577^{\mathrm{h}}$ \\
Penis & $(\mathrm{mg})$ & $460 \pm 39$ & $495 \pm 60$ \\
\hline
\end{tabular}

Males were sacrificed at four days after observation of copulation. 1): All data represent Mean \pm S.D. Student's t test : $\mathrm{P}<0.05$ a vs. b, c vs. d, e vs. f, g vs. h

val は, $657.3 \pm 320.6$ 秒であった。

\section{3 . 雌の平均着床痕数}

Table 3 に67および104週秢群の雄との交配に供 された雌の交配 8 日目の着床痕数について示した。 着床率は，67週跉群の $3 / 7$ 例 (43\%) に対し104週秢 群では0/12（0％) となり有意に低下した $(\mathrm{P}<$ 0.05）。平均着床痕数は67週齢群が5.4 46.8 個であ り, 着床痕数 0 の個体が $4 / 7$ 例（57\%）認められた が，104週秢群では全例が着床痕数 0 となった。

\section{4. 雄の生殖器重量}

Table 4 に67および104週秢群の交尾行動観察後 4 日目における雄ラットの生殖器重量を示した。体 重ならびに精巣, 精巣上体, 精襄腺の各重量は何れ も67週秢群に比べ104週秢群では有意に減少した $(\mathrm{P}<0.05)$ 。67週齢群に比べて104週秢群の值が前 立腺腹葉重量において低値を示し，陰事重量におい
て高値を示す傾向を認めたが有意な変化ではなかっ た。

雄の性機能が加柃によって減退する減少は多くの 哺乳動物で認められているが, 著者らが今回検討し た雄ラットの好孕能においても加橉と共に減少し, 44週秢では統計的な差が認められた。その後も暫時 減少し，95週龄で消失した。著者らと同じWistar -Imamichi 系ラットを使用した Hashizume らの報 告 [4]では, 生後 $30,31,59,60,93 お よ ひ ゙ 94$ 週龄で検 討しており，妊孕能を有する個体は $30 ・ 31$ 週秢では 85\%，59・60週秢では $35 \% ， 93 ・ 94$ 週跉では $0 \%$ で あったと述べている。本報では，29 31週龄では 98\%，59～61週秢では54\%，92９4週秢では 2\%の 個体に妊孕能が認められ，完全に消失したのは, 95 週橎であった。妊孕能の消失時期については, Hashizume らと同様の成績を得たが，その他の週粭では 何れも Hashizume らの成績よりも若干高い值を得 た。この原因として交配方法が考えられる。即ち, 著者らの方法は, 14 週跉以降, 連続週 $1 \sim 2$ 回の交 配を行った。この交配方法を採用した根拠は, 既報

[6]で述べたごとく非老龄動物において，連日交配 方法では翌日より妊孕能の低下がみられる [14]が, 週 1 2 回の交配方法では妊㔔能の低下がみられな いことや, 1 回の交配により低下した前立腺, 精亳· 凝固腺の各重量は 3 日後にほほ回復していること [13］などの成績に基づくものである。しかし， Hashizume ら [4]の方法は12週龄で 2 回交配した後

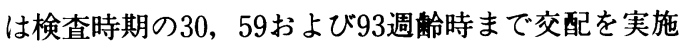
していない。この交配間隔の隔たり（交尾の休款期 間）がラットの妊孕能に影響を与えることが知られ ており, Weizenbaum ら [15] は週約 2 回交配して いるラットに比べて交尾後 6 週間目に交配した動物 では性行動と繁殖生理面の両活性の低下がみられる と述べている。また，著者らも10週龄から週 2 回交 配を 22 週間続けた後，12週間休䕀させたラットにお いて妊孕能の消失を経験している。従って, Hash izume ら [4] の成績の評価においては，加橉による 妊孕能の低下に交尾の休䕀期間の違いによって生ず る妊㔔能の低下を加味して考える必要がある。しか しながら著者らの成績と Hashizume らのそれは, 同一系統による成績のためか雄ラットの加橉に伴う 
妊孕能の低下割合において著しい差異は認められな かった。この加粭に伴う妊孕能低下と血中性腺ホル モンの動態について, Hashizume ら [4]は, 雄ラッ 卜の加柃に伴う妊孕能の減退は交尾能の低下に始ま ク，その減退は血中テストステロン濃度の減少およ びプロラクチン濃度の上䄯と深い関連性があるとし ている。同じく雄ラットでFrankel [2] は妊㔔能が 消失している老路雄ラット (108週秢) で血漿テスト ステロン濃度の低下を認め, 発情雌との同居におい ても，25，44週秢でみられた同居後の血漿テストス テロンおよび LH 濃度の増加は認められなかった としている。一方 Jakubczak[8]は, 老秢雄モルモッ トでテストステロンの不足を補填しても性行動の活 性化を認めていない。これらの報告より加秢性の妊 孕能の低下がテストステロンの低下のみの原因によ るものではないことが䇲える。

交尾行動の加秢性变化については, 既報 [6]では 総挿入回数は 10 週, 27 週, 44 週秢と週路の増加と共 に減少した。本報において，67週秢では44週秢とほ ほ同様の值を示したが暫時減少する傾向を示し, 104 週路では全く捚入行動は認められなかった。総射精 回数は, 既報 [6] では, 10 週粭が6.8 00.8 回, 27 週

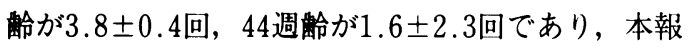

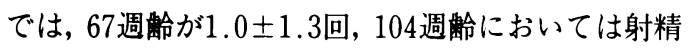
を示した個体は全く認められなかった。乗駕潜時お よび扱入潜時は, 既報 [6] では27週軨時に比べ44週 秢時は長くなる傾向を示し, 本報の67週㱓では44週 秢時とほほ同様の值であったが, 104週秢では乗駕ま でに長時間を要した。射精後挿入間間隔では, 既報 [6]では10週，27週，44週齢と週㱓と共に長くなる 傾向を示し, 本報の67週齢ではその間隔がさらに長 くなり,第 2 回目の射精シリーズに移行するまでに, 長時間を要している。既報 [6]において, 発情雌と の一晚同居による雄ラットの好孕能は10週および27 週龄群では100\%であったが, 44 週㱓群では $60 \%$ に低 下した。本報において，67週柃では3/7例 (42.9\%) とさらに減少した。妊娠した個体番号 5〜 7の個体 は通常の着床数を示した。また, 不妊の 4 例のうち, 個体番号 3 の個体の子宮は偽奼娠様であり, Fig. 2 の個体別行動パターンで示す様に，頻回の揮入が子 宮頸管を刺激し偽奸娠となったことが示唆される。 残る 3 例は子宮が貯留液で満たされ, 発情前期様を 呈していた。104週秢では全例が不奸であり，全ての 雌が性周期を回帰していた。
既報 [6] ならびに本報の成績より, 乗駕, 挿入, 射精からなる一連の交尾行動の加龄性変化として は, 乗駕回数, 插入回数および射精回数は加秢に伴っ て減少し, 乗駕潜時, 摴入潜時, 射精潜時および射 精後扦入間間隔は逆に加秢に伴って延長することが 明らかになった。そして, 射精回数の減少, 行動パ ターンの不規則化, 射精の消失, 㨂入の消失, 乗駕 の消失の順に加秢性変化が生ずることが認められ た。67週および104週軨での交尾行動を若い成熟雄 ラットのそれと比較すると，充分に発情状態にある 雌は若い成熟雄に対して, darting や ear-wiggling などの勧誘行動を示す。そして同居開始後 2 時間以 内で, 若い成熟雄は, 通常 $6 \sim 7$ 回の射精シリーズ を示し, 乗駕, 挿入, 射精からなる行動パターンも 極めて規則性が高い。これに対して Fig. 2 の乗駕の み，あるいは乗駕と㨂入行動しか見られなかった No. 1〜 4の個体, および Fig. 3 の乗駕行動のみしか 示さないNo. 8，9，14，15および17の個体との交配 に供した雌では, 若い成熟雄との交配に見られるよ うな darting 行動は殆ど認められない。従って雌の darting 行動と雄の性的活性との間には強い関連性 があるように思われる。また成績には示さなかった が, 雄の一連の交尾行動の中に雌の陰部に対する嗅 ぎ行動があり, 同居開始時や射精シリーズの開始時 には必ず見られる。この嗅ぎ行動の発現は，67週粭 までは全例に見られたが, 104週粭においては乗駕行 動を示した個体のみしか示さず, 交尾行動の加秢性 変化と嗅覚機能との関連の可能性が示唆された。こ れら交尾行動の加㱓性変化の原因については今後の 研究課題としたい。

\section{要 約}

雄ラット (Wistar-Imamichi 系) の妊孕能の加龄 性変化について検討した。14から40週㱓まで, 週秢 が進むと共に交配雌の産子.数 (着床数) は減少 (14.2〜12.0匹・個) する傾向を示したが, 統計的 に有意な変化ではなかった。しかし，44週秢（11.7 個）頃より有意差が認められ始め $(\mathrm{P}<$ 0.05 0.001)，95週粭では全例不妊となった、雄交 尾行動の加秢時の変化では, 乗嘿のみの発現率は67 週秢群が $100 \%, 104$ 週秢群が $42 \%$ であった。乗駕回 数は, 67 週秢群の $42.6 \pm 15.3( \pm \mathrm{SD})$ 回に対し, 104 週秢群は1.8土2.8回であった。挿入および射精は67 
週秢群にのみ認められ，その発現率と平均回数は挿 入が $86 \%$ と $10.3 \pm 10.2$ 回, 射精が $43 \%$ と $1.0 \pm 1.3$ 回 であった。乗駕潜時では，67週㱓群の535.4 5607.9 秒に対し104週跉群は $3,822.0 \pm 1,753.4$ 秒となり有 意に延長した $(\mathrm{P}<0.05)$ 。また, 67 週跉群の㨂入潜時

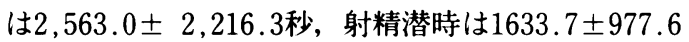
秒，射精後㨂入間間隔は657.3 3320.6 秒であった。 雌の妊娠率と着床数は 67 週秢群が $43 \%$ と $5.4 \pm 6.8$ 個 であり，104週舲群では全例が不妊であった(P< 0.05)。生殖器重量は, 104週䶖群では精巣, 精巣上 体および精襄重量が低值を示した $(\mathrm{P}<0.05)$ 。以上 のごとく, Wistar-Imamichi 系雄ラットにおける交 尾行動は加橉と共に減退し, 妊品能が完全に消失し た104週齢では乗駕行動を示す個体が少数認められ るものの，㨉入や射精行動を示す個体は全く認めら れなかった。

本実験結果の解析に際し適切な御助言を賜った (財) 動物繁 殖研究所所長の滝沢隆安博士および本実験を行うにあたって 惜しみない協力をいたたいた加藤公正, 佐々木淳一, 新村幸位 室員にお礼申し上げます。

\section{文 献}

[1] Beach, F. A. and Jordan, L. (1956). Sexual exhaustion and recovery in the male rat. Quart. $J$. Exp. Psychol., 8, 121-133.

[2] Frankel, A. I. (1981). Hormone release during computer-monitored sexual behavior in mature and aged male rats. Horm. Behav., 15, 312-320.

[3] Harman, S. M. (1978). Clinical aspects of aging of the male reproductive system. In The Aging Reproductive System, pp. 29-58, Schneider, E. L. (ed.), Raven Press, New York.

[4] Hashizume, K., Ikarashi, Y., Sakuma, S., and
Sakai, Y. (1984). The relationship between serum hormone levels and reproductive ability in aging male rats. Exp. Anim., 33 159-163.

[ 5 ] Heimer, L. and Larsson, K. (1967). Mating behavior of male rats after olfactory bulb lesions. Physiol . Behav., 2, 207-209.

[6] Hokao, R., Ito, T., Noguchi, J., Wakafuji, Y., Agematsu, Y., Saito, T. R., Takahashi, K. W., and Imamichi, T. (1992). Effect of age on the copulatory behavior of the male rat. Exp. Anim., 41, 259-268.

［7] 今道友則 (1961). 繁殖生理学およひ内分泌学に適する生 理的特徵を目標としたWistar-Imamichi Rat の育成 について, 日本臨床, 19, 99-109.

[8] Jakubczak, L. F. (1964). Effects of testosteron propionate on age differences in mating behvior. $J$. Gerontol. 19, 458-461.

[9] Larsson, K. (1958). Sexual behavior in senile male rats. J. Gerontol., 13, 136-139.

[10] Minnick, R. S., Warden, C. J., and Arieti, S. (1946). The effects of sex hormones on the copulatory behaviour of senile white rats. Science, 103, 749-750.

[11] Phoenix, C. G. and Chambers, K.C. (1982). Sexual behavior in aging male rhesus monkeys. In Advanced Views in Primate Biology, pp. 95-104, Chiavelli, A. B. and Corrucini, R. S. (eds.), Springer, Berlin.

［12］滝沢隆安 (1986)。一般統計解析ソフトウェア．文永堂, 東京.

[13］若藤靖匡 (1988). 多産系ラットに少数認められる低産子 数の母親を発現させる諸要因の探求と遗伝的に低産子 数を示す雄の選抜育成. pp. 145-147, 日獣者大.（博 士論文)。東京.

［14］若藤靖匡・高倉元史・外尾亮治・津江本由美子・高橋和 明・今道友則 (1985)。雄ラットの交配使用頻度と妊杂率 および着床数について，家畜繁殖誌，31，110-114.

[15] Weizenbaum, F. A., Mathews, M., Whitehouse, J., and Adler, N. (1981). Depressant effects of sexual rest on reproductive behavior and physiology in male rats. Biol. Reprod., 25, 747-751. 